INOBIS: Jurnal Inovasi Bisnis dan Manajemen Indonesia

Volume 02, Nomor 02, Maret 2019

Wulan Purnamasari, Dian Astri Indrayanti, Nurul Laili Fittriya

\title{
Pengaruh Gaya Kepemimpinan, Komunikasi Internal dan Motivasi Terhadap Kinerja Karyawan Pada Perusahaan
}

\author{
Wulan Purnamasari \\ Universitas Maarif Hasyim Latif \\ Dian Astri Indrayanti * \\ Universitas Maarif Hasyim Latif \\ Nurul Laili Fittriya \\ Universitas Maarif Hasyim Latif \\ *dianastriindrayanti@gmail.com
}

\begin{abstract}
Abstrak
Penelitian ini bermaksud untuk mengamati pengaruh gaya kepemimpinan, komunikasi internal dan motivasi terhadap kinerja karyawan PT. DutaCipta PakarPerkasa. Penelitian ini dilakukan terhadap karyawan PT. DutaCipta PakarPerkasa dengan sampel 81 karyawan. Metode pengambilan sampel dengan teknik Sampling Purposive, adalah metode penetapan sampel dengan proses evaluasi tertentu. Metode analysis data yang dipakai adalah Analisis Regresi Linier Berganda aplikasi SPSS 21.0 for windows.

Berdasarkan hasil analisis, gaya kepemimpinan secara parsial berpengaruh positif dan signifikan terhadap kinerja karyawan, menunjukkan nilai thitung 3,950> ttabel 1,989 dan signifikan sebesar $0,000<0,05$. Variabel komunikasi internal tidak berpengaruh positif dan signifikan terhadap kinerja karyawan, menunjukkan nilai thitung $0,947<$ ttabel 1,989 dan signifikan sebesar $0,347>0,05$. Sedangkan variabel motivasi berpengaruh positif dan signifikan terhadap kinerja karyawan, menunjukkan nilai thitung 5,111 > ttabel 1,989 dan signifikan sebesar $0,000<0,05$. Sehingga, bisa dikatakan secara simultan atau bersama-sama variabel gaya kepemimpinan, komunikasi internal dan motivasi berpengaruh positif dan signifikan terhadap kinerja karyawan. Hasil analisis menunjukkan nilai koefisien determinasi (R2) sebesar 0,627. Artinya, ketiga variabel gaya kepemimpinan, komunikasi internal dan motivasi secara bersama-sama memberikan kontribusi sebesar $62,7 \%$ terhadap kinerja karyawan, sedangkan sisanya sebesar 37,3\% merupakan sumbangan atau kontribusi variabel berbeda yang tidak diteliti pada penelitian ini.
\end{abstract}

Kata Kunci: Gaya Kepemimpinan, Komunikasi Internal, Motivasi, Kinerja Karyawan.

\section{Pendahuluan}

Dalam mencapai sasaran organisasi, setiap organisasi membutuhkan sumber daya untuk mencapainya. Sumber daya itu seperti sumber daya alam, sumber daya finansial, sumber daya ilmu pengetahuan, teknologi dan sumber daya manusia. Diantara sumber daya tersebut, sumber daya yang terpenting ialah sumberdaya manusia. Sumber daya manusia memiliki kontribusi amat berharga dalam sebuah organisasi, terutama disebuah perusahaan. Sumber daya manusia pada perusahaan, menyebabkan sebuah perusahaan harus membuat anggaran sejumlah dana yang cukup besar untuk pengembangan sumber daya dalam beragam macam upaya.

Beberapa upaya yang dilakukan perusahaan dalam rangka meningkatkan dan mengendalikan sumber daya manusia diantaranya melalui motivasi, disiplin kerja dan lingkungan kerja. Hal tersebut dilakukan agar keberhasilan suatu perusahaan dapat tercapai. Meskipun suatu perusahaan mempunyai sumber daya lain yang baik, seperti perangkat kerja 


\section{Wulan Purnamasari, Dian Astri Indrayanti, Nurul Laili Fittriya}

yang canggih, namun jika sumber daya manusia yang dimiliki tidak bermutu dan tidak mendapatkan pengelolaan yang baik, maka perusahaan tentu menghadapi masalah ketika mencapai tujuannya. Ini menunjukkan bahwa sumber daya manusia mempunyai peran penting dalam pertumbuhan dan pengembangan perusahaan, karena potensi yang ada dalam diri manusia seperti bakat, kreativitas dan keinginan mampu mencapai tujuan perusahaan.

Dalam pencapaian target perusahaan banyak faktor - faktor yang menjadi perkara penting dalam pencapaiannya, antara lain adalah faktor kepemimpinan atau pemimpin. Peranan pemimpin sangat berpengaruh, seperti memanfaatkan kewenangan dan kepemimpinan nya guna menggapai target.

Dalam sebuah perusahaan, tentu memiliki seorang atasan yang memegang peran sebagai panutan yang membawahi sebuah organisasi atau perusahaan. Kepemimpinan dalam organisasi ini memiliki tatanan yang berjenjang, dimana setiap divisi pasti terdapat karyawan yang lebih tinggi jabatannya yang biasanya disebut pimpinan. Pimpinan dalam setiap divisi tentu berbeda, karena setiap individu mempunyai gaya kemimpinan yang beragam. Tipe kepemimpinan dalam manajemen umumnya berbeda tiap masing - masing divisi dikarenakan kebutuhan divisi itu sendiri. Bawahan bekerja kerap tergantung pada pimpinan. Jika pimpinan tidak mempunyai kompetensi memimpin, maka tugas-tugasnya tidak mampu dilaksanakan dengan baik. Sebuah organisasi memerlukan pemimpin yang efektif, yang memiliki keahlian mempengaruhi sikap anak buahnya. Tanpa adanya pimpinan, kegiatan perusahaan mungkin tidak akan berjalan. Hal ini dapat mengakibatkan kurangnya pencapaian tujuan perusahaan.

Selain gaya kepemimpinan, ada beberapa yang mampu mempengaruhi kinerja karyawan seperti komunikasi internal, lingkungan kerja dan motivasi. Komunikasi internal adalah komunikasi yang terjadi di area perusahaan. Komunikasi internal yaitu penyampaian berita dari seseorang pada orang lain. Komunikasi ini dapat berlangung antara atasan dengan bawahan, bawahan dengan bawahan, maupun atasan dengan atasan. Komunikasi dikatakan berhasil jika timbul saling memahami antara pihak yang menyampaikan dengan pihak penerima, sehingga apa yang disampaikan bisa dipahami, difikirkan dan dilaksanakan. Lingkungan kerja merupakan keadaan lingkungan disekitar perusahaan. Selama melakukan pekerjaan, karyawan akan berhubungan dengan berbagai situasi yang ada dalam lingkungan kerja. Selain itu, motivasi juga sangat mempengaruhi kinerja karyawan. Motivasi adalah kemauan untuk melaksanakan sebagai kemampuan guna mengeluarkan usaha yang maksimal untuk tujuan-tujuan organisasi.

PT. DutaCipta PakarPerkasa merupakan perusahaan bergerak dibidang manufaktur baja dan pengembangan infrastruktur. Tepatnya PT. DutaCipta PakarPerkasa, di Jl. Wringinanom Km 37, Kedung Anyar, Gresik, East Java - Indonesia. Perusahaan tersebut didirikan pada tahun 1982 dengan banyak proyek diseluruh provinsi di Indonesia. Pembangunan perusahaan dicabang Gresik bertujuan untuk memperluas area produksi, serta memberi peluang kerja untuk tenaga kerja yang belum mendapatkan lapangan pekerjaan. Dengan banyaknya proyek yang ditangani, merupakan hasil dari kinerja sumber daya manusianya. Output tersebut tidak luput dari pengelolaan menajemen terhadap sumber daya manusianya.

Di PT. DutaCipta PakarPerkasa dimana setiap pemimpin mempunyai gaya kepemimpinan yang beragam. Setiap gaya kepemimpinan memiliki pengaruh positif maupun negatif terhadap kinerja bawahan nya. Aspek komunikasi internal juga merupakan aspek penting atas berhasilnya suatu tujuan dalam masing - masing divisi. Kemudain motivasi, motivasi menjadi sangat penting untuk menjadi semangat karyawan dalam melaksanakan tanggung jawabnya sebagai karyawan dalam kinerja nya dimana dalam era globalisasi ini, tentu kebutuhan karyawan kian meningkat seiring perkembangan jaman. Namun beberapa tahun terakhir, perusahaan mengalami penurunan output dan sedikitnya project yang dikerjakan. 
Banyaknya complain dari customer dan terlambatnya proses fabrikasi jauh dari schedule yang sudah ditentukan.

Dengan memperhatikan penjelasan tersebut diatas, dan berdasarkan pengalaman bekerja di PT. DutaCipta PakarPerkasa, penulis tertarik mengambil judul "Pengaruh Gaya Kepemimpinan, Komunikasi Internal dan Motivasi terhadap Kinerja Karyawan PT. DutaCipta PakarPerkasa". Penelitian mengenai pengaruh gaya kepemimpinan, komunikasi internal dan motivasi terhadap kinerja karyawan merupakan suatu penelitian untuk mengetahui bagaimana cara mengatasi permasalahan yang dialami perusahaan tersebut.

\section{Rumusan Masalah}

1. Apakah gaya kepemimpinan berpengaruh positif dan signifikan terhadap kinerja karyawan di PT. DutaCipta PakarPerkasa?

2. Apakah komunikasi internal berpengaruh positif dan signifikan terhadap kinerja karyawan PT. DutaCipta PakarPerkasa?

3. Apakah motivasi kerja berpengaruh positif dan signifikan terhadap kinerja karyawan PT. DutaCipta PakarPerkasa?

4. Diantara variabel gaya kepemimpinan, komunikasi internal dan motivasi manakah yang lebih mempunyai nilai dominan?

5. Apakah gaya kepemimpinan, komunikasi internal dan motivasi berpengaruh secara simultan terhadap kinerja karyawan PT. DutaCipta PakarPerkasa?

\section{Tujuan Penelitian}

1. Untuk mengetahui apakah gaya kepemimpinan berpengaruh positif dan signifikan terhadap kinerja karyawan di PT. DutaCipta PakarPerkasa

2. Untuk mengetahui apakah komunikasi internal berpengaruh positif dan signifikan terhadap kinerja karyawan PT. DutaCipta PakarPerkasa

3. Untuk mengetahui apakah motivasi berpengaruh positif dan signifikan terhadap kinerja karyawan PT. DutaCipta PakarPerkasa

4. Untuk mengetahui variabel manakah yang mempunyai nilai dominan terhadap kinerja karyawan PT. DutaCipta PakarPerkasa

5. Untuk mengetahui pengaruh gaya kepemimpinan, komunikasi internal dan motivasi secara simultan terhadap kinerja karyawan PT. DutaCipta PakarPerkasa

\section{Landasan Teori dan Pengembangan Hipotesis}

\section{Manajemen Sumber Daya Manusia}

Menurut Desseler, (2015:3) manajemen sumber daya manusia merupakan metode untuk memperoleh, menilai, melatih dan mengompensasi karyawan dan untuk mengurus relasi tenaga kerja, kesehatan dan keselamatan, serta hal - hal yang berkaitan dengan keadilan.

\section{Gaya Kepemimpinan}

Gaya kepemimpinan menurut Rivai, (2014:42) menyatakan Gaya Kepemimpinan merupakan sekumpulan ciri yang dimanfaatkan pimpinan untuk mempengaruhi bawahan agar target organisasi tercapai atau dapat pula dikatakan bahwa gaya kepemimpinan adalah pola perilaku dan strategi yang disukai dan sering diterapkan oleh seorang pemimpin.

Menurut Miftah Thoha ada empat indikator gaya kepemimpinan yang biasa dipakai dalam pengambilan keputusan :

1. Instruksi, gaya pemimpin tipe ini mempunyai ciri komunikasi satu arah. Pemimpin memberi batasan kontribusi pengikutnya dan memberitahu mereka tentang apa, 


\section{Wulan Purnamasari, Dian Astri Indrayanti, Nurul Laili Fittriya}

bagaimana, bilamana, dan dimana melaksanakan berbagai tugas. Inisiatif penyelesaian masalah dan pengambilan keputusan semata-mata dilakukan oleh pemimpin.

2. Konsultasi, sikap pemimpin ini tinggi pengarahan dan tinggi dukungan. Pemimpin masih banyak menyampaikan pengarahan dan masih membuat hampir sama dengan keputusan, tetapi hal ini diikuti dengan meningkatnya komunikasi dua arah dan perilaku mendukung. Meskipun dukungan ditingkatkan, pengendalian (control) atas pengambilan keputusan tetap pada pemimpin.

3. Partisipasi, pemimpin dengan gaya kepemimpinan partisipasi, lebih memfokuskan pada dukungan tetapi rendah pengarahan, karena posisi control atas penyelesaian masalah dan pengambilan keputusan dipegang secara bergantian. Pemimpin dan pengikut saling tukar-menukar ide dalam penyelesaian masalah dan pembuatan keputusan. Tanggung jawab penyelesaian masalah dan pembuatan keputusan sebagian besar berada pada pihak pengikut.

4. Delegasi, perilaku pemimpin ini rendah dukungan dan rendah pengarahan atas tugas yang diberikan kepada bawahan. Bawahanlah yang memiliki control untuk memutuskan tentang bagaimana cara pelaksanaan tugas. Pemimpin memberikan kesempatan yang luas bagi bawahan untuk melaksanakan pertunjukan mereka sendiri karena mereka memiliki kemampuan dan keyakinan untuk memikul tanggung jawab dalam pengarahan perilaku mereka sendiri. Gaya kepemimpinan delegasi banyak terdapat pada structural pemerintahan. (Thoha, 2012:66-68)

\section{Komunikasi Internal}

Zelko dan Dance (dalam Muhammad, 2014:66) mengatakan komunikasi organisasi suatu system yang saling tergantung mencakup komunikasi internal dan komunikasi eksternal. Komunikasi internal adalah komunikasi dalam organisasi itu sendiri seperti komunikasi dari bawahan kepada atasan, komunikasi dari atasan kepada bawahan, komunikasi sesama karyawan yang sama tingkatannya.

Menurut Suranto AW, (2011:105) ada beberapa indikator komunikasi kerja, meliputi :

1. Pemahaman

Merupakan kemampuan memahami pesan secara cermat sebagaimana dimaksudkan oleh komunikator.

2. Kesenangan

Apabila proses komunikasi itu selain berhasil menyampaikan informasi, juga dapat berlangsung dalam suasana yang menyenangkan kedua belah pihak. Sebenarnya tujuan berkomunikasi tidaklah sekedar transaksi pesan, akan tetapi dimaksudkan pula untuk saling interaksi secara menyenangkan untuk memupuk hubungan insani.

3. Hubungan yang makin baik

Bahwa dalam proses komunikasi yang efektif secara tidak sengaja meningkatkan kadar hubungan interpersonal. Di perkantoran, seringkali terjadi komunikasi dilakukan bukan untuk menyampaikan informasi atau mempengaruhi sikap semata, tetapi kadang terdapat maksud implisit disebaliknya, yakni untuk membina hubungan baik.

4. Tindakan kedua belah pihak

Yang berkomunikasi melakukan tindakan sesuai dengan pesan yang dikomunikasikan. Komunikasi efektif menuntut kepekaan antara kedua belah pihak.

\section{Motivasi}

Pamela \& Oloko, (2015) Motivasi adalah kunci dari organisasi yang sukses untuk menjaga kelangsungan pekerjaan dalam organisasi dengan cara dan bantuan yang kuat untuk 
bertahan hidup. Motivasi adalah memberikan bimbingan yang tepat atau arahan, sumber daya dan imbalan agar mereka terinspirasi dan tertarik untuk bekerja dengan cara yang anda inginkan.

Menurut Zameer, Ali, Nisar dan Amir, (2014:297), indikator dari motivasi kerja menurut mereka ada 5 yang mengacu kepada 2 dimensi yaitu:

1. Monetary motivational

a. Gaji. Pemberian upah secara tepat waktu dan penetapan gaji sesuai dengan pekerjaannya maka akan membuat kebiasaan baik karyawan meningkat.

b. Bonus. Bonus yang diberikan oleh perusahaan berdasarkan kinerja karyawan tersebut akan meningkatkan produktivitas perusahaan.

2. Non-monetary motivational

a. Jaminan kesejahteraan karyawan. Jaminan tersebut meliputi hak cuti, jaminan kesehatan yang ditanggung oleh perusahaan, hak mendapatkan jatah rumah, dan lain sebagainya.

b. Perasaan aman memiliki pekerjaan. Hal-hal yang dapat memicu motivasi akan membuat karyawan merasa aman karena bekerja di perusahan itu.

c. Promosi. Pengembangan dan peningkatan karir yang ditawarkan perusahaan akan membuat seorang karyawan bertahan di perusahaan tersebut dalam waktu yang lama atau bahkan sampai pensiun.

\section{Kinerja Karyawan}

Mangkunegara, (2009) dalam jurnal Setyowati \& Haryani, (2016) mengemukakan bahwa istilah kinerja dari kata job performance atau actual performance (prestasi kerja atau prestasi sesungguhnya) yaitu hasil kerja secara kualitas dan kuantitas yang dicapai oleh seorang pegawai dalam melaksanakan tugasnya sesuai dengan tanggung jawab yang diberikan padanya.

Menurut Setiawan, (2014:147) untuk mengukur kinerja dapat menggunakan indikatorindikator sebagai berikut :

a. Ketepatan penyelesaian tugas

Merupakan pengelolaan waktu dalam bekerja dan juga ketepatan karyawan dalam menyelesaikan pekerjaan.

b. Kesesuaian jam kerja

Kesediaan karyawan dalam mematuhi peraturan perusahaan yang berkaitan dengan ketepatan waktu masuk atau pulang kerja dan jumlah kehadiran.

c. Tingkat kehadiran

Jumlah ketidak hadiran karyawan dalam suatu perusahaan selama periode tertentu.

d. Kerjasama antar karyawan

Kemampuan karyawan untuk bekerja sama dengan orang lain dalam menyelesaikan suatu tugas yang ditentukan sehingga mencapai daya guna yang sebesar-besarnya.

e. Kepuasan kerja

Karyawan merasa puas dengan jenis pekerjaan yang menjadi tanggung jawabnya dalam perusahaan. 


\section{Kerangka Konseptual}

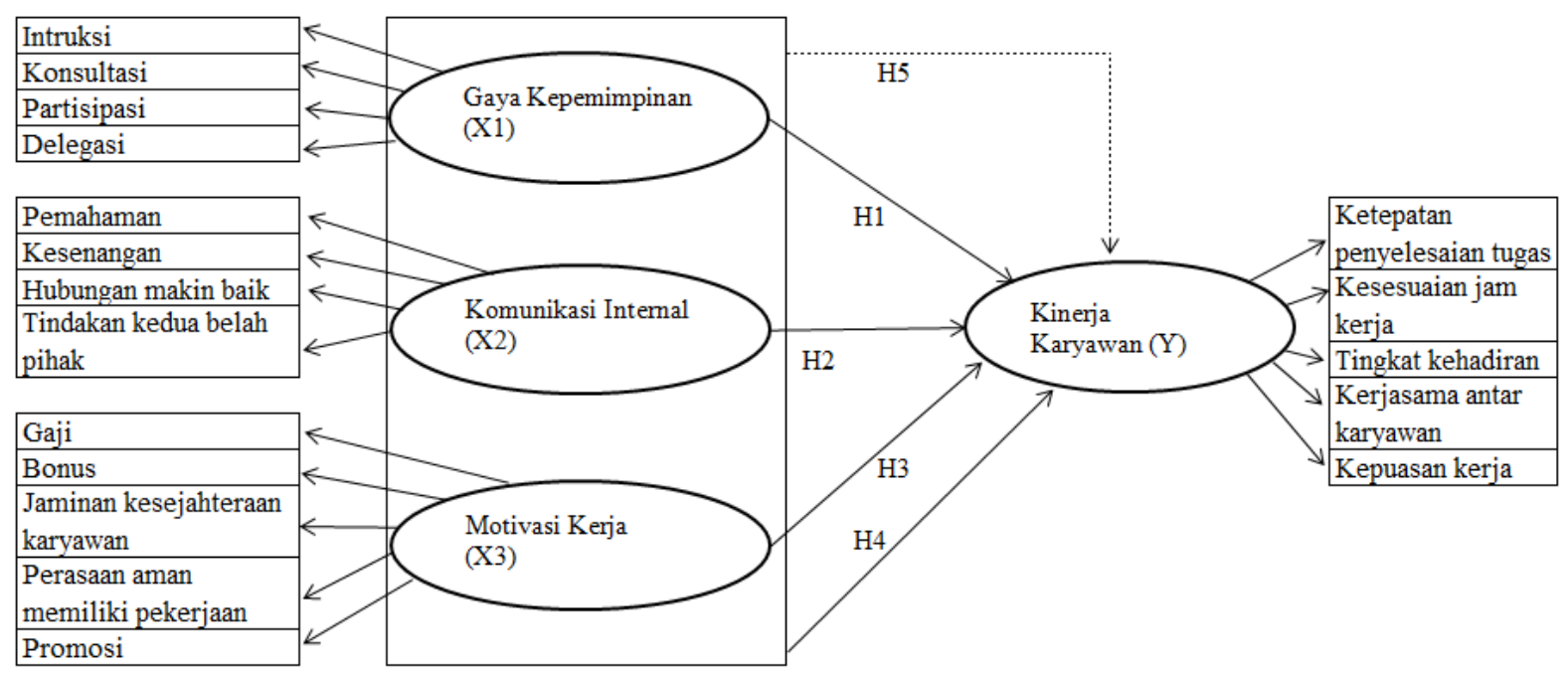

Gambar 1. Kerangka Konseptual (Data Diolah)

\section{Hipotesis Pengembangan}

Dari uraian diatas, penulis mengungkap hipotesis penelitian yang berjudul "Pengaruh Gaya Kepemimpinan, Komunikasi Internal dan Motivasi terhadap Kinerja Karyawan PT. DutaCipta PakarPerkasa" sebagai berikut :

H1 : Diduga gaya kepemimpinan berpengaruh positif dan signifikan terhadap kinerja karyawan di PT. DutaCipta PakarPerkasa

H2 : Diduga komunikasi internal berpengaruh positif dan signifikan terhadap kinerja karyawan PT. DutaCipta PakarPerkasa H3 : Diduga motivasi kerja berpengaruh positif dan signifikan terhadap kinerja karyawan PT. DutaCipta PakarPerkasa

H4 : Diduga gaya kepemimpinan yang mempunyai nilai dominan terhadap kinerja karyawan PT. DutaCipta PakarPerkasa

H5 :Diduga gaya kepemimpinan, komunikasi internal dan motivasi secara simultan berpengaruh positif dan signinfikan terhadap kinerja karyawan PT. DutaCipta PakarPerkasa

\section{Metode Penelitian}

\section{Variabel Penelitian}

\section{Variabel Bebas / Independence Variable (X)}

Menurut Sugiyono, (2013:44) pengertian variabel independen adalah "Varibel yang mempengaruhi atau menjadi sebab perubahan nya atau timbul nya variabel dependen (terikat)". Variabel X dalam penelitian ini, dapat didefinisikan secara operasional sebagai berikut :

1. Gaya Kepemimpinan (X1) adalah sekumpulan ciri yang digunakan pimpinan untuk mempengaruhi bawahan agar sasaran organisasi tercapai atau dapat pula dikatakan bahwa gaya kepemimpinan adalah pola perilaku dan strategi yang disukai dan sering diterapkan oleh seorang pemimpin. 
INOBIS: Jurnal Inovasi Bisnis dan Manajemen Indonesia Volume 02, Nomor 02, Maret 2019

Wulan Purnamasari, Dian Astri Indrayanti, Nurul Laili Fittriya

Indikator gaya kepemimpinan antara lain :

a. Intruksi

b. Konsultasi

c. Partisipasi

d. Delegasi

2. Komunikasi Internal (X2) adalah komunikasi dalam organisasi itu sendiri seperti komunikasi dari bawahan kepada atasan, komunikasi dari atasan kepada bawahan, komunikasi sesama karyawan yang sama tingkatannya.

Indikator komunikasi internal antara lain:

a. Pemahaman

b. Kesenangan

c. Hubungan yang makin baik

d. Tindakan kedua belah pihak

3. Motivasi (X3) adalah memberikan bimbingan yang tepat atau arahan, sumber daya dan imbalan agar mereka terinspirasi dan tertarik untuk bekerja dengan cara yang anda inginkan.

Indikator motivasi antara lain :

a. Gaji

b. Bonus

c. Jaminan kesejahteraan karyawan

d. Perasaan aman memiliki pekerjaan

e. Promosi

\section{Variabel Terikat / Dependence Variable (Y)}

Menurut Sugiyono, (2013:39) pengertian variabel dependen adalah variabel yang dipengaruhi atau yang menjadi akibat, karena adanya variabel bebas". Dalam penelitian ini yang menjadi variabel dependen (Y) adalah :

1. Kinerja Karyawan (Y) adalah hasil dari suatu proses yang mengacu dan diukur selama periode waktu tertentu berdasarkan ketentuan atau kesepakatan yang telah ditetapkan sebelumnya.

Indikator kinerja karyawan adalah sebagai berikut :

a. Ketepatan penyelesaian tugas

b. Kesesuaian jam kerja

c. Tingkat kehadiran

d. Kerjasama antar karyawan

e. Kepuasan kerja

\section{Populasi Penelitian}

Populasi yang menjadi obyek penelitian ini adalah karyawan PT Duta Cipta Pakar Perkasa bagian kantor yang berstatus karyawan tetap, kontak maupun tenaga harian lepas yang beroperasi dalam sektor pengadaan dan konstruksi.

\section{Sampel Penelitian}

Teknik pengambilan sampel dalam penelitian ini adalah Nonprobability Sampling. Nonprobability Sampling yaitu metode pengambilan sampel yang tidak memberi peluang yang sama bagi setiap unsur (anggota) populasi untuk dipilih menjadi anggota sampel (Sugiyono 2011:66). Jenis Nonprobability Sampling yang digunakan adalah Sampling Purposive, merupakan metode pemilihan sampel dengan evaluasi tertentu (Sugiyono, 2011:68). 
Sampel penelitian ini ditentukan sebanyak 81 karyawan atau sebagian karyawan office, yang meliputi department : Plant, Engineering, HRD \& GA, PPIC, Finance, Logistik, ICT, QHSE, WIP, Produksi dan Maintenance.

\section{Data yang Digunakan}

Data primer yang dipakai pada penelitian ini adalah kuesioner. Penelitian ini, pengambilan dan pengolahan data berdasarkan pada kuesioner yang disebarkan ke responden. Data sekunder merupakan data yang diperoleh secara tidak langsung dari sumbernya melainkan dari pihak lain. Metode dalam pengambilan data dilakukan melalui cara peneliti mendalami, menelaah, mencermati, dan mengidentifikasi pengetahuan yang ada dalam perpustakaan yang berasal dari sumber bacaan, internet, buku-buku referensi, jurnal, atau hasil penelitian terdahulu untuk menunjang penelitian lanjutan.

\section{Pembahasan}

Metode Analis yang Digunakan

Hasil Uji Validitas

Tabel 1. Uji Validitas

\begin{tabular}{|c|l|c|c|c|}
\hline No & Indikator & $\begin{array}{l}\text { Nilai Korelasi } \\
\text { (Pearson } \\
\text { Correlation) }\end{array}$ & $\begin{array}{l}\text { Probabilitas Korelasi } \\
\text { [Sig. (2-tailed) }\end{array}$ & Ket \\
\hline 1 & Intruksi & 0,805 & 0 & Valid \\
\hline 2 & Konsultasi & 0,856 & 0 & Valid \\
\hline 3 & Partisipasi & 0,831 & 0 & Valid \\
\hline 4 & Delegasi & 0,713 & 0 & Valid \\
\hline 5 & Pemahaman & 0,85 & 0 & Valid \\
\hline 6 & Kesenangan & 0,808 & 0 & Valid \\
\hline 7 & Hubungan makin baik & 0,74 & 0 & Valid \\
\hline 8 & Tindakan kedua belah pihak & 0,655 & 0 & Valid \\
\hline 9 & Gaji & 0,632 & 0 & Valid \\
\hline 10 & Bonus & 0,75 & 0 & Valid \\
\hline 11 & $\begin{array}{l}\text { Jaminan } \\
\text { karyawan }\end{array}$ & 0,838 & 0 & Valid \\
\hline 12 & $\begin{array}{l}\text { Perasaan aman memiliki } \\
\text { pekerjaan }\end{array}$ & 0,695 & 0 & Valid \\
\hline 13 & Promosi & 0,846 & 0 & Valid \\
\hline 14 & $\begin{array}{l}\text { Ketepatan penyelesaian } \\
\text { tugas }\end{array}$ & 0,826 & 0 & Valid \\
\hline 15 & Kesesuaian jam kerja & 0,856 & 0 & Valid \\
\hline 16 & Tingkat kehadiran & 0,845 & Valid \\
\hline 17 & Kerjasama antar karyawan & 0,715 & 0 & Valid \\
\hline 18 & Kepuasan kerja & & 0 & 0 \\
\hline Referaan & & 0 & 0 \\
\hline
\end{tabular}

(Referensi: Hasil Output SPSS) 
Berdasarkan pada tabel diatas, menunjukkan bahwa indikator yang digunakan untuk mengukur variabel-variabel dikatakan valid. Karena nilai korelasi tiap indikator menunjukkan nilai rhasil > rtabel sebesar 0,2159 dan mempunyai nilai probabilitas 0,000.

Tabel 2. Hasil Uji Reliabilitas

\begin{tabular}{|l|c|c|c|}
\hline Variabel & $\begin{array}{l}\text { Cronbach's Alpha if } \\
\text { Item Deleted }\end{array}$ & $\begin{array}{l}\text { Cronbach's Alpha } \\
\text { yang disyaratkan }\end{array}$ & Ket \\
\hline Gaya kepemimpinan $\left(\mathrm{X}_{1}\right)$ & 0,816 & 0,6 & Reliable \\
\hline Komunikasi internal $\left(\mathrm{X}_{2}\right)$ & 0,837 & 0,6 & Reliable \\
\hline Motivasi $\left(\mathrm{X}_{3}\right)$ & 0,847 & 0,6 & Reliable \\
\hline Kinerja karyawan $(\mathrm{Y})$ & 0,792 & 0,6 & Reliable \\
\hline
\end{tabular}

(Referensi: Hasil Output SPSS)

Berdasarkan hasil pengujian reliabilitas diatas, menunjukkan bahwa masing - masing variabel gaya kepemimpian (X1), komunikasi internal (X2), motivasi (X3) dan kinerja karyawan (Y) memiliki nilai cronbach's alpha $>0,60$. Jadi, bisa disimpulkan hasil uji reliabilitas terhadap keseluruhan variabel adalah reliable.

\section{Uji Regresi Berganda}

Tabel 3. Uji Regresi Berganda

\section{Coefficients $^{\mathrm{a}}$}

\begin{tabular}{|c|c|c|c|c|c|c|}
\hline \multirow{2}{*}{\multicolumn{2}{|c|}{ Model }} & \multicolumn{2}{|c|}{$\begin{array}{l}\text { Unstandardized } \\
\text { Coefficients }\end{array}$} & \multirow{2}{*}{$\begin{array}{l}\text { Standardized } \\
\text { Coefficients } \\
\text { Beta }\end{array}$} & \multirow[b]{2}{*}{$\mathrm{t}$} & \multirow{2}{*}{ Sig. } \\
\hline & & B & $\begin{array}{l}\text { Std. } \\
\text { Error }\end{array}$ & & & \\
\hline & (Constant) & $\begin{array}{l}3.23 \\
5 \\
\end{array}$ & 1.465 & & 2.208 & .030 \\
\hline & $\begin{array}{l}\text { Gaya } \\
\text { kepemimp } \\
\text { inan (X1) }\end{array}$ & .461 & .117 & .396 & 3.950 & .000 \\
\hline 1 & $\begin{array}{l}\text { Komunika } \\
\text { si internal } \\
\text { (X2) }\end{array}$ & .119 & .126 & .094 & .947 & .347 \\
\hline & $\begin{array}{l}\text { Motivasi } \\
\text { (X3) }\end{array}$ & .414 & .081 & .432 & 5.111 & .000 \\
\hline
\end{tabular}

a. Dependent Variable: Kinerja karyawan (Y)

(Referensi: Hasil Output SPSS)

Dari persamaan regresi linier diatas memperoleh penjelasan yaitu :

a. Konstanta $\alpha$ sebesar 3,235 menunjukkan bahwa semua variabel memiliki sumbangsih kepada kinerja karyawan sebesar 3,235\%, artinya setiap satu kesatuan dari ketiga variabel secara bersama - sama akan memberikan pertambahan nilai 3,235. Hal ini ditunjukkan dengan bersama - sama nya pengaruh ketiga variabel independen yaitu 
gaya kepemimpinan, komunikasi internal dan motivasi dengan nilai 3,235. Nilai tersebut dicapai oleh ketiga variabel secara bersama - sama berpengaruh terhadap kinerja karyawan, apabila ketiga variabel tersebut memiliki seriap peningkatan satu dari ketiga variabel bersama - sama, maka kinerja karyawan naik 3,235. Jika ketiga variabel mempunyai kenaikan dua maka menjadi 2 x 3,235 dan seterusnya.

b. Koefisien regresi gaya kepemimpinan $(\mathrm{b} 1)=0,461$. Menunjukkan variabel gaya kepemimpinan memiliki pengaruh sebesar 0,461 terhadap kinerja karyawan. Besarnya koefisien regresi variabel bebas gaya kepemimpinan (X1) artinya setiap peningkatan gaya kepemimpinan satu satuan maka memberikan sumbangsih kepada peningkatan kinerja karyawan sebesar 0,461 dengan perkiraan variabel bebas yang lain dari model regresi tidak berubah.

c. Koefisien regresi komunikasi internal $(\mathrm{b} 2)=0,119$. Menunjukkan bahwa variabel komunikasi internal mempunyai pengaruh sebesar 0,119 terhadap kinerja karyawan dengan. Hal ini menyatakan setiap kenaikan komunikasi internal belum tentu mempengaruhi kinerja karyawan, dengan perkiraaan variabel bebas yang lain dari model regresi tidak berubah.

d. Koefisien regresi motivasi $(b 3)=0,414$. Menyatakan variabel motivasi mempunyai pengaruh sebesar 0,414 terhadap kinerja karyawan. Besarnya koefisien regresi variabel bebas motivasi (X3) artinya setiap peningkatan motivasi satu satuan maka memberikan sumbangsih kepada peningkatan kinerja karyawan sebesar 0,414 dengan perkiraan bahwa variabel bebas yang lain dari model regresi tidak berubah.

\section{Uji Hipotesis}

1. Pengaruh gaya kepemimpinan terhadap kinerja karyawan.

Variabel gaya kepemimpinan (X1) dengan nilai thitung 3,950 > ttabel 1,989 dan hasil probabilitas signifikan sebesar 0,000 <0,05. Maka H0 ditolak dan Ha diterima. Dengan demikian, disimpulkan bahwa variabel gaya kepemimpinan berpengaruh positif dan signifikan terhadap kinerja karyawan.

2. Pengaruh komunikasi internal terhadap kinerja karyawan.

Variabel komunikasi internal (X2) dengan nilai thitung 0,947 < ttabel 1,989 dan hasil probabilitas signifikan sebesar 0,347>0,05. Maka H0 diterima dan Ha ditolak. Dengan demikian, disimpulkan bahwa variabel komunikasi internal tidak berpengaruh positif dan signifikan terhadap kinerja karyawan.

3. Pengaruh motivasi terhadap kinerja karyawan.

Variabel motivasi (X3) dengan nilai thitung 5,111 > ttabel 1,989 dan hasil probabilitas signifikan sebesar 0,000<0,05. Maka H0 ditolak dan Ha diterima. Dengan demikian, variabel motivasi berpengaruh positif dan signifikan terhadap kinerja karyawan. 
INOBIS: Jurnal Inovasi Bisnis dan Manajemen Indonesia

Volume 02, Nomor 02, Maret 2019

Wulan Purnamasari, Dian Astri Indrayanti, Nurul Laili Fittriya

\section{Uji Simultan (Uji F)}

Tabel 4. Uji Simultan (Uji F)

\begin{tabular}{|c|c|c|c|c|c|c|}
\hline \multicolumn{7}{|c|}{ ANOVA $^{\mathrm{a}}$} \\
\hline \multicolumn{2}{|c|}{ Model } & Sum of Squares & df & $\begin{array}{l}\text { Mean } \\
\text { Square }\end{array}$ & $\mathrm{F}$ & Sig \\
\hline \multirow{3}{*}{1} & $\begin{array}{l}\text { Regres } \\
\text { sion }\end{array}$ & 361.197 & 3 & 120.399 & $\begin{array}{l}43.1 \\
84\end{array}$ & .00 \\
\hline & $\begin{array}{l}\text { Residu } \\
\text { al }\end{array}$ & 214.680 & 77 & 2.788 & & \\
\hline & Total & 575.877 & 80 & & & \\
\hline \multicolumn{7}{|c|}{ a. Dependent Variable: Kinerja karyawan (Y) } \\
\hline \multicolumn{7}{|c|}{$\begin{array}{l}\text { b. Predictors: (Constant), Motivasi (X3), Komunikasi internal (X2), } \\
\text { Gaya kepemimpinan (X1) }\end{array}$} \\
\hline
\end{tabular}

Dari tabel diatas, menunjukkan Fhitung 43,184 sedangkan Ftabel sebesar 2,72. Angka 2,72 tersebut diperoleh dari tabel $\mathrm{F}$ dengan nilai v1 sebesar 3 sebagai residual dan v2 sebesar 77 sebagai df (derajat kebebasan) dengan taraf kesalahan 0,05 (5\%). Mengingat nilai Fhitung 43,184 > Ftabel 2,72 dengan tingkat signifikansi 0,000 > 0,05. Maka seluruh variabel independen $(\mathrm{X})$ secara simultan berpengaruh positif dan signifikan terhadap variabel dependen (Y). Dengan demikian H0 ditolak dan Ha diterima. Tabel diatas menunjukkan bahwa hipotesis yang mengatakan bahwa ada pengaruh yang positif dan signifikan antara gaya kepemimpinan, komunikasi internal dan motivasi secara bersama - sama terhadap kinerja karyawan bisa diterima dan teruji secara statistik.

1. Pengaruh Gaya Kepemimpinan Terhadap Kinerja Karyawan di PT. Dutacipta Pakarperkasa

Hipotesis pertama terbukti kebenaran nya. Hal ini diketahui dari hasil thitung 3,950 > ttabel 1,989 dengan signifikansi 0,000 $<0,05$. Berdasarkan uji hipotesis tersebut, H1 diterima. Hal tersebut sesuai dengan dugaan penulis, karena nilai thitung 3,950 > ttabel 1,989. Sehingga dapat disimpulkan gaya kepemimpinan berpengaruh positif dan signifikan terhadap kinerja karyawan di PT. DutaCipta PakarPerkasa.

2. Pengaruh komunikasi internal terhadap kinerja karyawan PT. DutaCipta PakarPerkasa Hipotesis kedua tidak terbukti kebenaran nya. Hal ini diketahui dari hasil thitung 0,947 $<$ ttabel 1,989 dengan signifikansi 0,347 > 0,05 Berdasarkan uji hipotesis tersebut, H2 ditolak. Hal tersebut tidak sesuai dengan dugaan penulis, karena nilai thitung 0,947 < ttabel 1,989. Sehingga dapat disimpulkan, komunikasi internal tidak berpengaruh positif dan signifikan terhadap kinerja karyawan di PT. DutaCipta PakarPerkasa.

3. Pengaruh Motivasi Kerja Terhadap Kinerja Karyawan PT. DutaCipta PakarPerkasa Hipotesis ketiga terbukti kebenaran nya. Hal ini diketahui dari hasil thitung 5,111 > ttabel 1,989 dengan signifikansi $0,000<0,05$. Berdasarkan uji hipotesis tersebut, H3 diterima. Hal tersebut sesuai dengan dugaan penulis, karena nilai thitung 5,111 > ttabel 1,989. Sehingga dapat disimpulkan motivasi berpengaruh positif dan signifikan terhadap kinerja karyawan di PT. DutaCipta PakarPerkasa.

4. Pengaruh Gaya Kepemimpinan Berpengaruh Terhadap Kinerja Karyawan PT. DutaCipta PakarPerkasa 


\section{Wulan Purnamasari, Dian Astri Indrayanti, Nurul Laili Fittriya}

Hipotesis keempat tidak terbukti kebenaran nya. Hal ini diketahui dari hasil thitung 3,950 > ttabel 1,989 dengan signifikansi 0,000 < 0,05. Hasil pengujian diatas lebih kecil dari variabel motivasi yakni thitung 5,111 > ttabel 1,989 dengan signifikansi 0,000< 0,05. Sehingga dapat disimpulkan gaya kepemimpinan tidak memiliki nilai dominan terhadap kinerja karyawan di PT. DutaCipta PakarPerkasa. Berdasarkan uji hipotesis tersebut, H4 ditolak. Hal tersebut tidak sesuai dengan dugaan penulis, karena hasil penelitian variabel gaya kepemimpinan memiliki nilai thitung 3,950 > ttabel 1,989 lebih kecil dari variabel motivasi dengan thitung 5,111 > ttabel 1,989. Dapat disimpulkan bahwa yang mempunyai nilai dominan yaitu variabel motivasi dengan thitung 5,111 > ttabel 1,989 dan signifikansi $0,000<0,05$.

5. Pengaruh Gaya Kepemimpinan, Komunikasi Internal dan Motivasi Secara Simultan Berpengaruh Positif dan Signifikan Terhadap Kinerja Karyawan PT. DutaCipta PakarPerkasa

Hipotesis kelima terbukti kebenaran nya. Hal ini diketahui dari hasil Fhitung 43,184 > Ftabel 2,72 dengan signifikansi 0,000 >0,05. Berdasarkan uji hipotesis tersebut, H5 diterima. Hal tersebut sesuai dengan dugaan penulis, karena hasil dari penelitian menyatakan Fhitung 43,184 > Ftabel 2,72. Sehingga dapat disimpulkan gaya kepemimpinan, komunikasi internal dan motivasi secara simultan berpengaruh positif dan signifikan terhadap kinerja karyawan PT. DutaCipta PakarPerkasa.

\section{Kesimpulan}

Sesuai hasil penelitian yang dilakukan, maka kesimpulan yang dapat dikemukakan dalam penelitian ini sebagai berikut :

1. Variabel gaya kepemimpinan (X1) berpengaruh positif dan signifikan terhadap kinerja karyawan di PT. DutaCipta PakarPerkasa. Dengan thitung 3,950 > ttabel 1,989, sehingga H0 ditolak dan Ha diterima. Artinya semakin baik gaya kepemimpinan, kinerja karyawan akan semakin meningkat.

2. Variabel komunikasi internal (X2) tidak mempunyai pengaruh terhadap kinerja karyawan PT. DutaCipta PakarPerkasa. Dengan thitung 0,947 < ttabel 1,989, sehingga HO diterima dan Ha ditolak. Artinya komunikasi internal yang baik, belum tentu meningkatkan kinerja karyawan.

3. Variabel motivasi (X3) berpengaruh positif dan signifikan terhadap kinerja karyawan PT. DutaCipta PakarPerkasa. Dengan thitung 5,111 > ttabel 1,989, sehingga H0 ditolak dan Ha diterima. Artinya semakin tinggi motivasi, kinerja karyawan akan semakin meningkat.

4. Variabel gaya kepemimpinan (X1) tidak mempunyai nilai dominan terhadap kinerja karyawan PT. DutaCipta PakarPerkasa. Dengan thitung 3,950 > ttabel 1,989. Hasil pengujian tersebut lebih kecil dari variabel motivasi yakni thitung 5,111 > ttabel 1,989. Sehingga yang mempunyai nilai dominan yaitu variabel motivasi.

5. Secara simultan variabel gaya kepemimpinan (X1), komunikasi internal (X2) dan motivasi (X3) berpengaruh positif dan signinfikan terhadap kinerja karyawan PT. DutaCipta PakarPerkasa. Dengan Fhitung 43,184 > Ftabel 2,72. Sehingga H0 ditolak dan Ha diterima. 
INOBIS: Jurnal Inovasi Bisnis dan Manajemen Indonesia Volume 02, Nomor 02, Maret 2019

Wulan Purnamasari, Dian Astri Indrayanti, Nurul Laili Fittriya

\section{Daftar Pustaka}

Alfajar, Muhammad Rasyad. (2014) "Analisis Kinerja Keuangan Bank Syariah Devisa dan Bank Syariah Non Devisa dengan Metode RGEC". Jurnal mahasiswa UIN Sunan Kalijaga

Katiandagho., S.L. Mandey., L. Mananeke. (2014) "Pengaruh Disiplin Kerja Kepemimpinan dan Motivasi Terhadap Kinerja Pegawai pada PT. PLN (PERSERO) Wilayah Suluttenggo Area Manado". Jurnal Vol.2 No.3 September 2014.

Mangkunegara, Anwar Prabu. (2017) "Manajemen Sumber Daya Manusia Perusahaan" Penerbit PT. Remaja Rosdakarya, Bandung.

Pamela, A.O., \& Oloko (2015) Effect of Motivation on Employee Performance of Commercial Banks in Kenya: A Case Study of Kenya Commercial Bank in Migori County. Journal of Human Resource Studies 5 (2).

Rayadi. (2012). "Faktor Sumber Daya Manusia Yang Meningkatkan Kinerja Karyawan dan Perusahaan Di Kalbar". Skripsi Pontianak: AMIK Panca Bhakti Pontianak

Rivai. (2014) "Kepemimpinan dan Perilaku Organisasi”. Jakarta: PT. Raja Grafindo Persada

Selvia, Mirza. (2014) "Pengaruh Motivasi, Disiplin Kerja dan Lingkungan Kerja Terhadap Kinerja Karyawan PT. Inti General Yaja Steel Semarang”. Jurnal 2014.

Setiawan, Ferry dan Dewi, Kartika. (2014) "Pengaruh Kompensasi Dan Lingkungan Kerja Terhadap Kinerja Karyawan pada CV. Berkat Anugrah”. Jurnal. Denpasar: Universitas Udayana.

Sugiyono. (2018). "Metode Penelitian Kuantitatif, Kualitatif dan R\&D”. Penerbit CV. Alfabeta, Bandung. ISBN 979-8433-64-0

Suranto A.W. (2011) "Komunikasi Perkantoran "Prinsip Komunikasi untuk Meningkatkan Kinerja Perkantoran". Yogyakarta: Media Wacana

Susilowati, Sri. (2016) "Dampak Pengelolaan Sumberdaya Manusia Terhadap Semangat Kerja Karyawan PT Bukit Jaya Abadi Surabaya" Surabaya. Jurnal, Vol. 3 No.2. September 2016

Roscahyo, Agung. (2013) "Pengaruh Gaya Kepemimpinan Terhadap Kinerja Karyawan Pada Rumah Sakit SitiKhodijah Sidoarjo”. Skripsi. Surabaya: Sekolah Tinggi Ilmu Ekonomi Indonesia.

Zameer, H., Ali, S., Nisar, W., Amir, M. (2014, January). The impact of the Motivation on the Employee's Performance In Beverage Industry of Pakistan. International Journal of Academy Research in Accounting, Finance \& Management Sciences, 4(1), 293-298. 